\title{
Interfaces
}

\section{The Frustrating and Frustrated Edge: Thoughts on the format of my work}

\section{Aliki Braine}

\section{(2) OpenEdition}

1 Journals

\section{Electronic version}

URL: https://journals.openedition.org/interfaces/2733

DOI: 10.4000/interfaces.2733

ISSN: 2647-6754

\section{Publisher:}

Université de Bourgogne, Université de Paris, College of the Holy Cross

\section{Printed version}

Date of publication: 12 July 2021

ISSN: 1164-6225

\section{Electronic reference}

Aliki Braine, "The Frustrating and Frustrated Edge: Thoughts on the format of my work", Interfaces [Online], 45 | 2021, Online since 12 July 2021, connection on 15 September 2021. URL: http:// journals.openedition.org/interfaces/2733; DOI: https://doi.org/10.4000/interfaces.2733

This text was automatically generated on 15 September 2021.

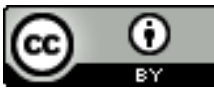

Les contenus de la revue Interfaces sont mis à disposition selon les termes de la Licence Creative Commons Attribution 4.0 International. 


\title{
The Frustrating and Frustrated Edge: Thoughts on the format of my work
}

\author{
Aliki Braine
}

1 This short paper examines my relationship as an artist with the format of my photographic images and the decisions I make about the edges of my prints. It is presented in conjunction with and as additional to images of my photographic work. The format of my work is an integral part of my practice and it is informed by precedents from the history of both painting and photography. As a result, I have been thinking about how and why the photographic edge plays such a huge role in the conception, and hopefully the reception, of my work.

2 According to legend and the subject of Johann Michael Wittmer's Raphael's First Sketch of the 'Madonna della Sedia' of 1853, the great master Raphael, being caught unexpectedly in need of a surface on which to capture the scene of a young peasant mother and her children which he stumbled upon in the campagna, was given a barrel top on which to sketch as the only available surface. This apocryphal narrative is used to explain the circular format of his Madonna della Sedia (Fig. 1). Contrastingly, in the history of art, the rectangular picture, whether photographic, painted or drawn, is far more common, necessitating an explanation to Raphael's use of the atypical tondo format. Pictures are systematically surrounded and contained by the straight edges of the rectangle; they are, in one way or another, framed. 
Figure 1. Johann Michael Wittmer, Raphael's First Sketch of the 'Madonna della Sedia' (1853). Detail. Oil on canvas, $98.3 \times 74.6 \mathrm{~cm}$.

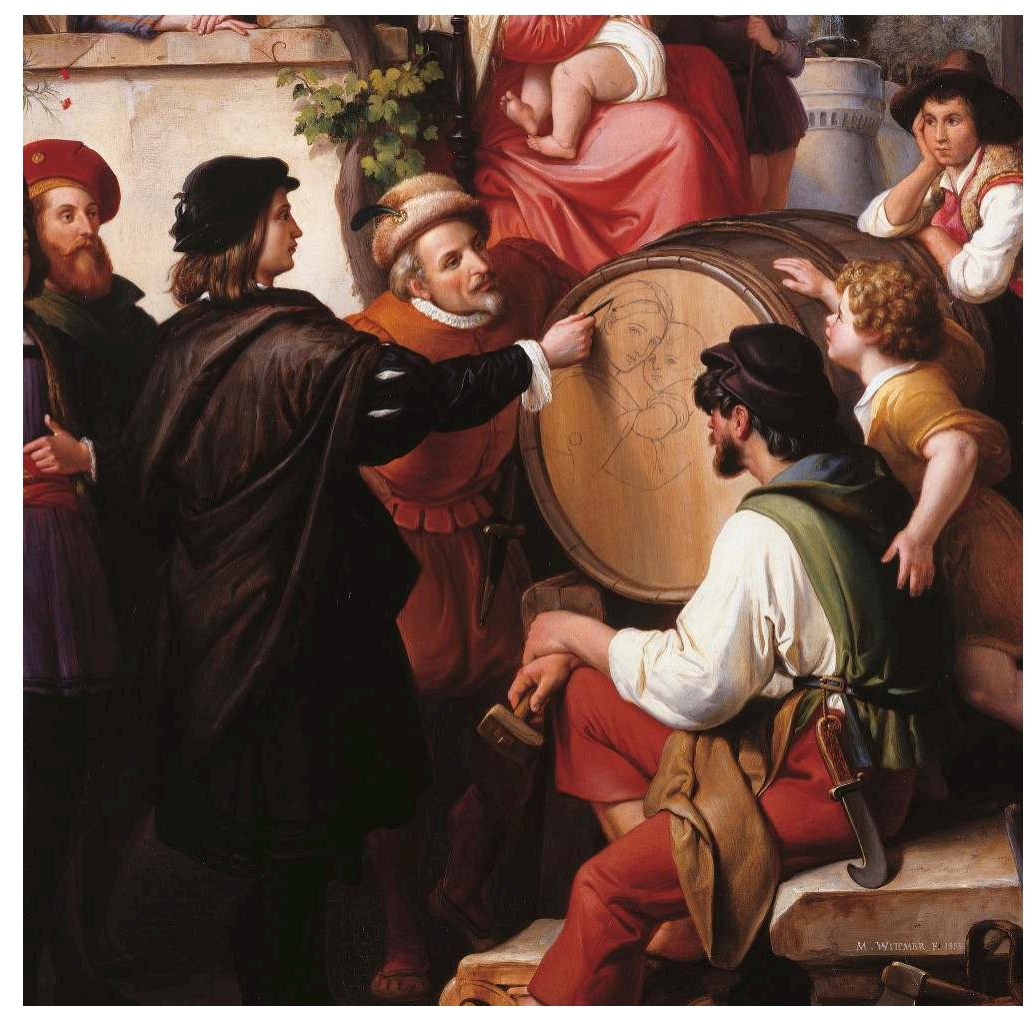

(C) Royal Collection Trust. HTTPS://WWW.RCT.UK/COLLECTION/403635/RAPHAELS-fiRST-SKETCH-OFTHE-MADONNA-DELLA-SEDIA.

3 Broadly speaking, my work explores the physical nature of photographic images and the debt photography owes to historical western European painting. It points to the 'object-ness' of an image that originates in a negative that has been exposed in a camera and printed in the darkroom. In a sense, the object is just a piece of photosensitive paper with a front and a back. By folding, drawing with ink, punching holes or overlaying negatives with adhesive stickers, I manipulate the pristine surface of the negative, forcing the viewer to acknowledge the photograph as an object and the image as a construct. By obscuring parts of the image, I aim to trigger a recognition of the photographic process and of its medium. At the same time, all these strategies also point to the format of my resulting images; I don't simply alert the viewer to the fact that the photograph had a format, which I have now disrupted in some way; I also create a new format all of my own making.

Rampant and recurrent rectangularity tends to obscure the fact that other formats have co-existed with it. So much to do with vision, for example, turns out to be circular; the eye, the lens, the pupil, the field of vision. It is only when it comes to representing the visible that the format in which this is undertaken has straight edges. It is worth wondering why vision transformed into representation seems to require a change of shape. My own work tends to feature lots of circles: circular edges, the use of circular stickers, circles within squares, circular cuts, circular negatives and re-oriented circular segments of the original image. Some of my most recent bodies of prints made in 2019-20, including A Thousand Falling Petals, Pieces of Sky, Pieces of Water and Entr'acte, 
are all made by using small circular negative 'confetti' scattered on the darkroom enlarger (Figs. 2-8)

Figure 2. Aliki Braine, Entracte (2020). Colour photographs from negative confetti, $23 \times 28 \mathrm{~cm}$.
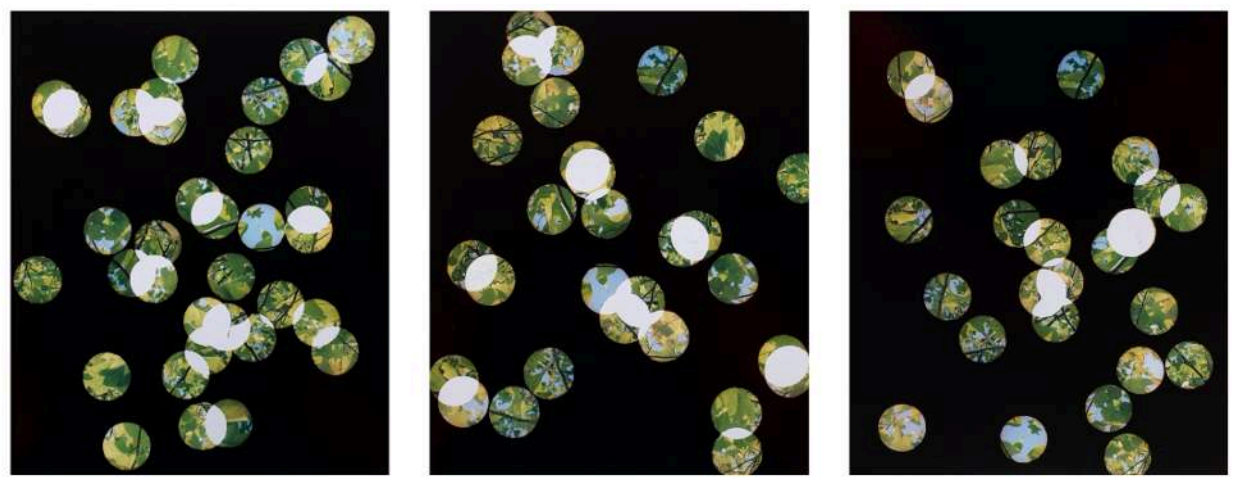

(c) Courtesy of the artist.

Figure 3. Aliki Braine, Entracte (2020). Detail. Colour photographs from negative confetti, $23 \times 28$ $\mathrm{cm}$.

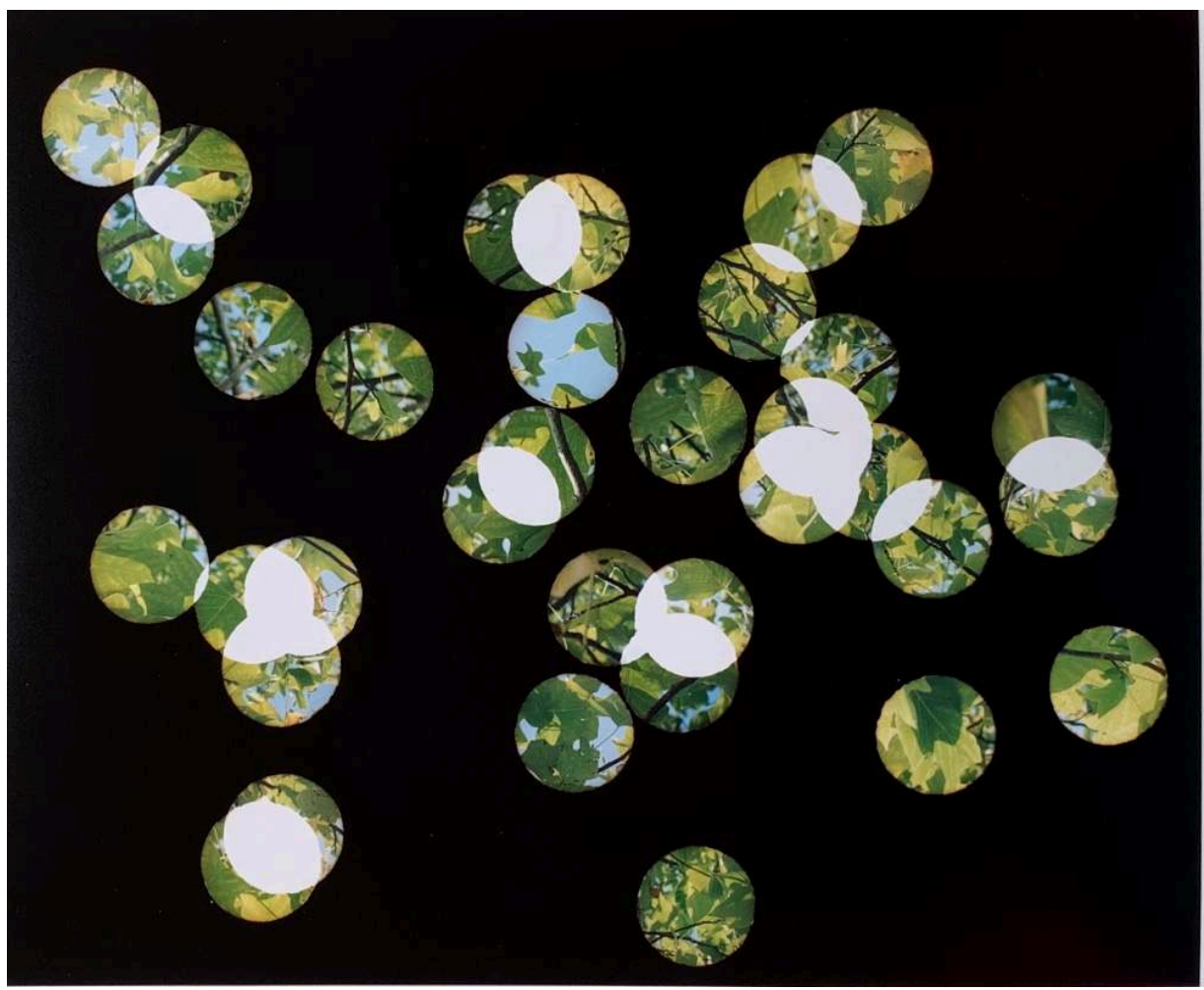

(c) Courtesy of the artist. 
Figure 4. Aliki Braine, A Thousand Falling Petals (2019). Colour photographs from negative confetti, $48 \times 58 \mathrm{~cm}$.
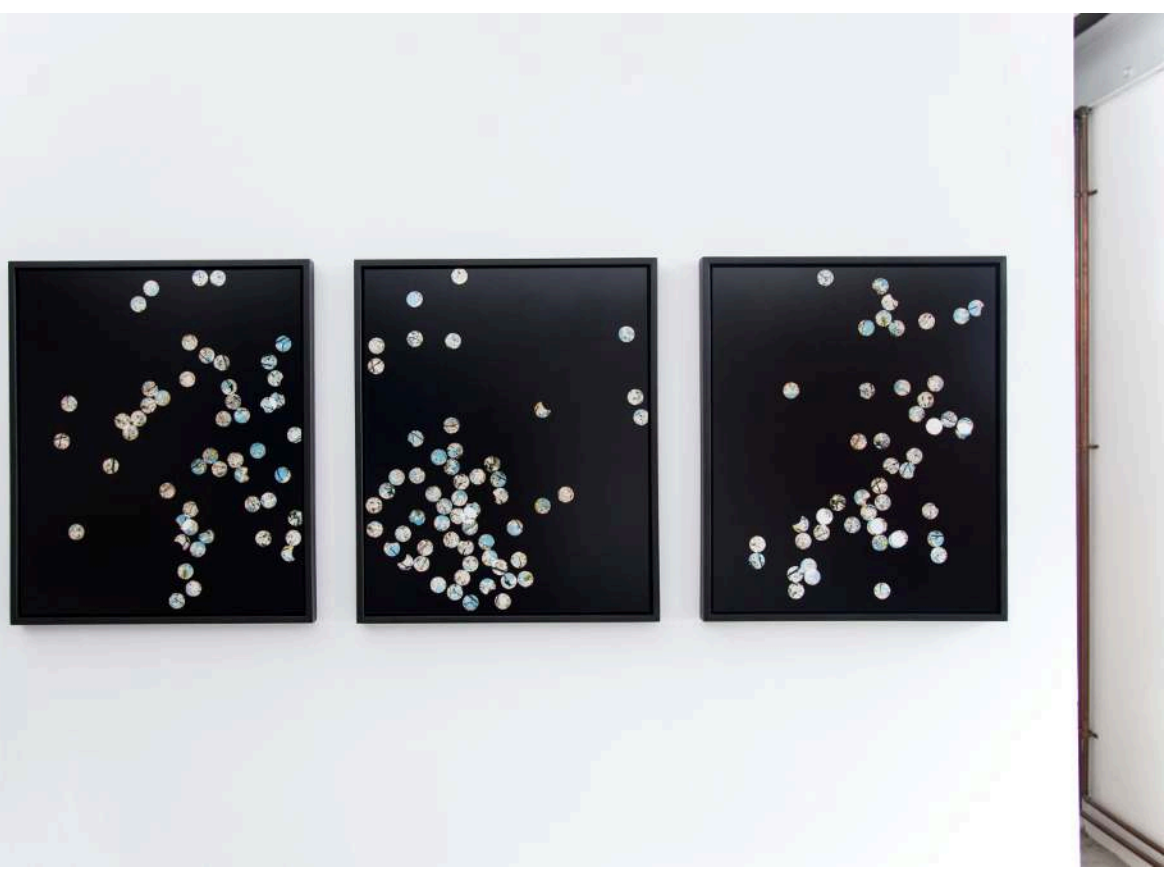

(c) Courtesy of the artist.

Figure 5. Aliki Braine, $A$ Thousand Falling Petals (2019). Detail. Colour photographs from negative confetti, $48 \times 58 \mathrm{~cm}$.

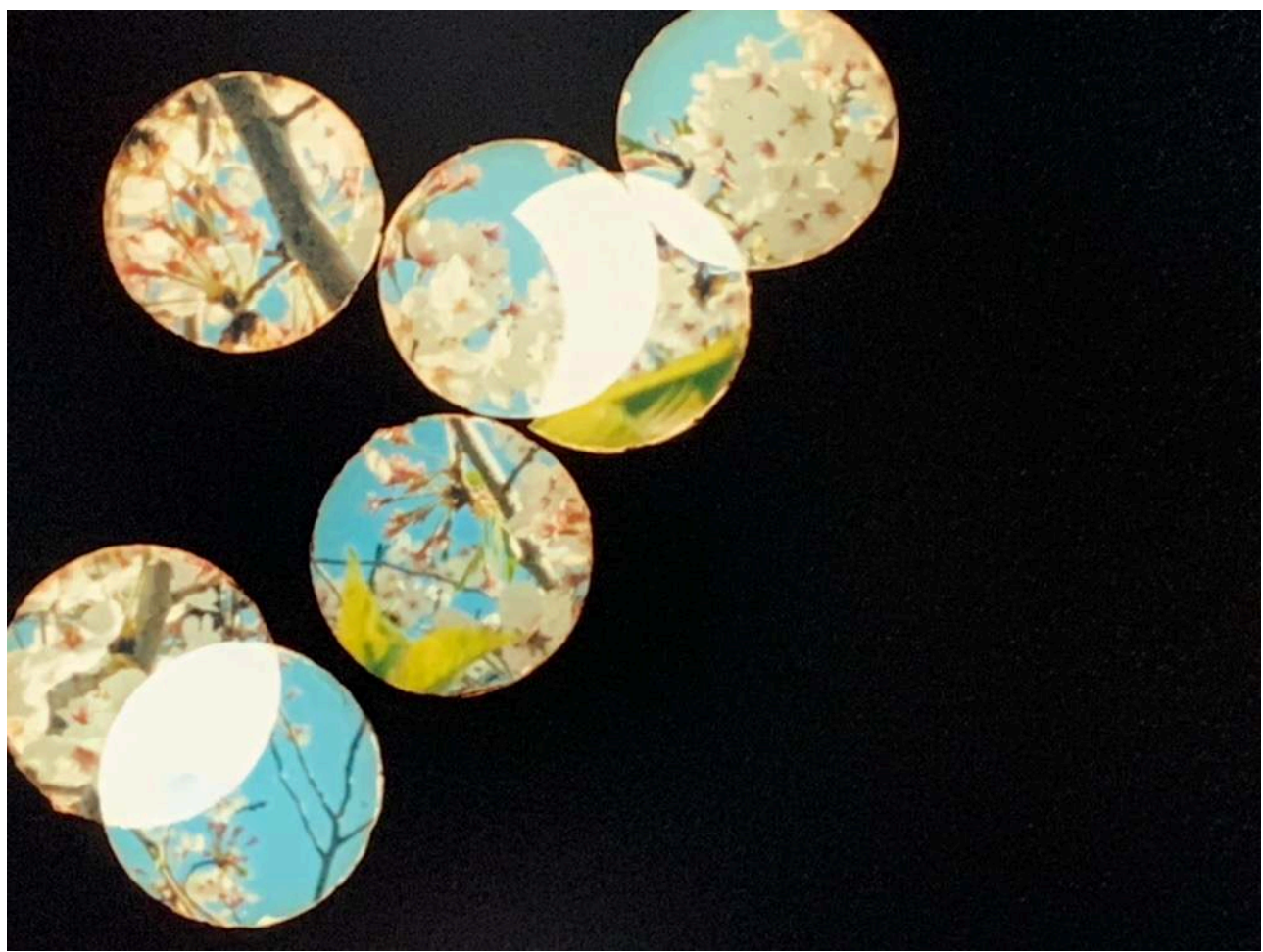

(c) Courtesy of the artist. 
Figure 6. Aliki Braine, Pieces of Water (2020). Colour photographs from negative confetti, variable dia.

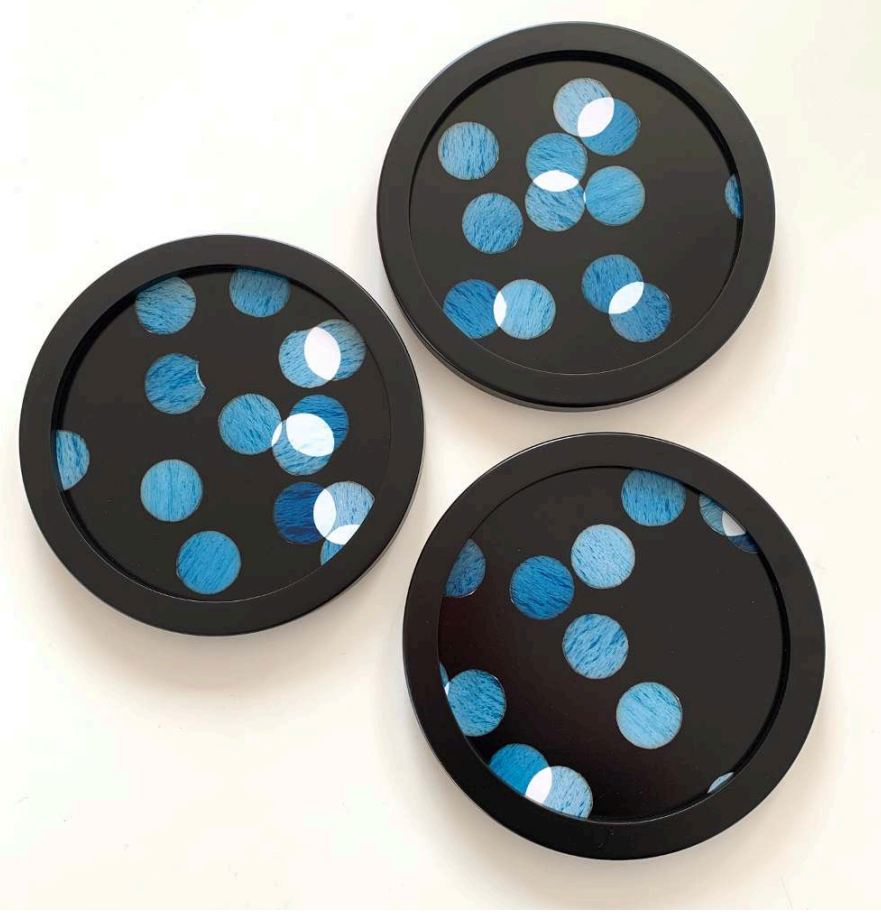

(c) Courtesy of the artist.

Figure 7. Aliki Braine, Pieces of Sky (2020). Colour photographs from negative confetti, variable dia.

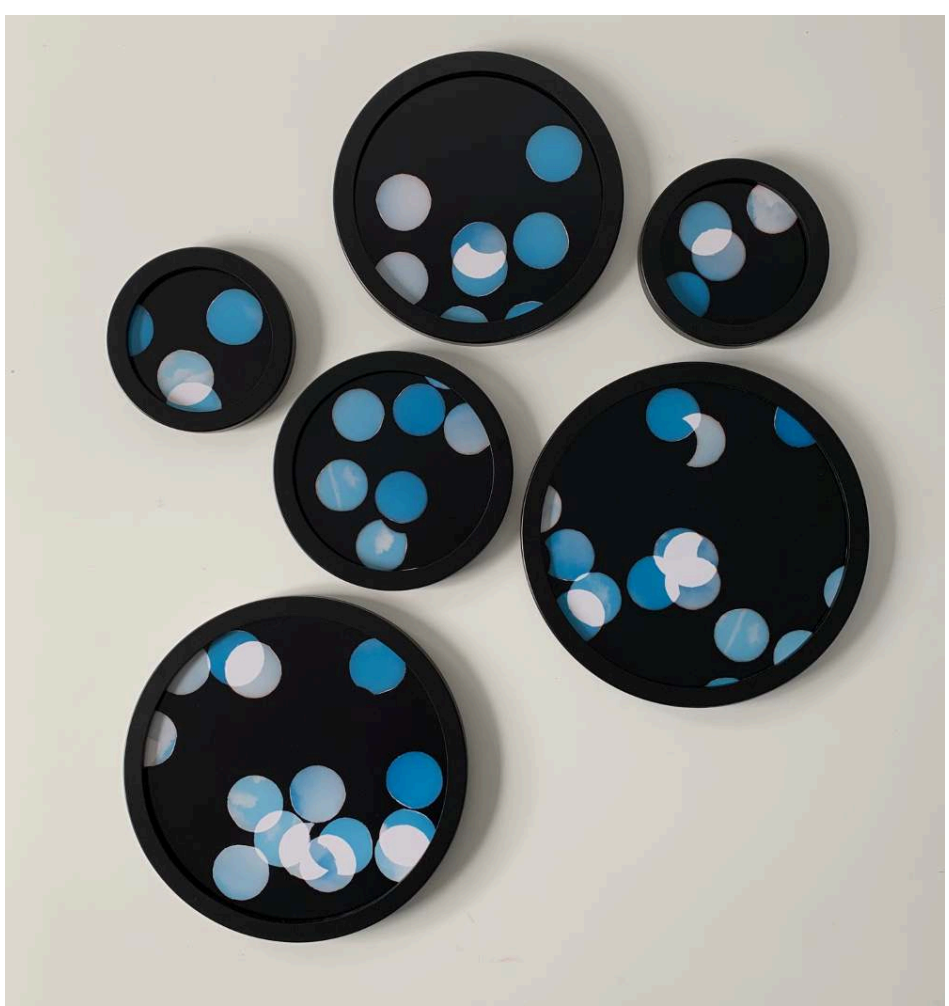

(c) Courtesy of the artist. 
Figure 8. Aliki Braine, negatives.

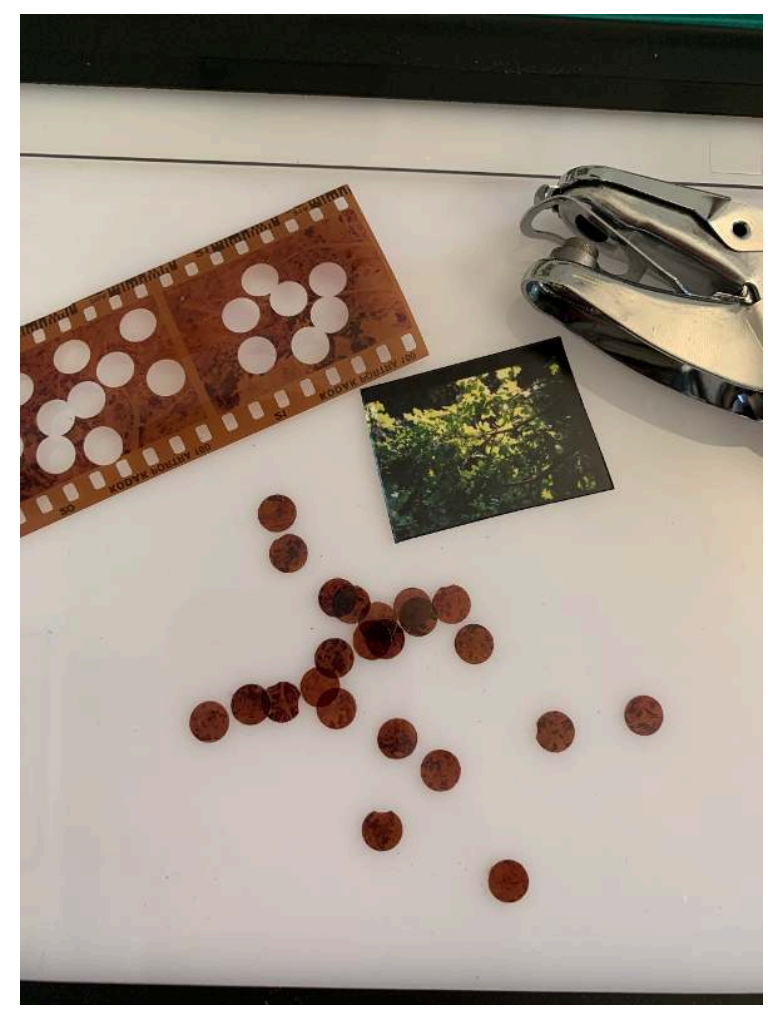

(C) Courtesy of the artist.

A circular border does not just feature as a consequence of happenstance in the story of the inception of Raphael's Madonna della Sedia, the circle also frames other important histories and narratives of representation and creation. In photography, the first mass consumer point-and-shoot camera, the Kodak 1, which was launched in 1888 and was the forerunner of the celebrated brownie camera, included 100-frames of pre-loaded film which when exposed, sent to and then returned from the Kodak-Eastman factory, produced a set of circular prints. This circular trimming of the first generation of photographic snapshots, artfully cropped the inevitable peripheral distortion of early mass-produced photographic lenses. In line with the democratic possibilities of camera ownership and image creation unleashed by the Kodak 1, it also meant that amateur photographers didn't need to have to worry too much about the positioning of the camera against the straight line of the horizon; prints could be rotated to make the horizon line horizontal if the shot had been taken at a skewed angle. ${ }^{1}$

In my own work, the use of the circular edge is not just to do with a desire to echo this history of photography, it also hopes to remind viewers that the camera is a replica of the human eye; the edge of human vision is circular and the human eye sees upside down. In the $17^{\text {th }}$ century, the camera obscura was accepted once and for all as a mechanical replica of the human eye. ${ }^{2}$ In my body of work entitled In the Beginning (2017), I remind the viewer that we physically see the world upside-down (Fig. 9). Like in the camera obscura, light, which reflects off the outside world, passes through the window of our cornea and the lens of our pupils and is reflected in reverse to cast an image on the back of our retina. 
Figure 9. Aliki Braine, In the beginning... (Sky) (2017). Black and white photograph from cut and repositioned negative, $60 \times 60 \mathrm{~cm}$.

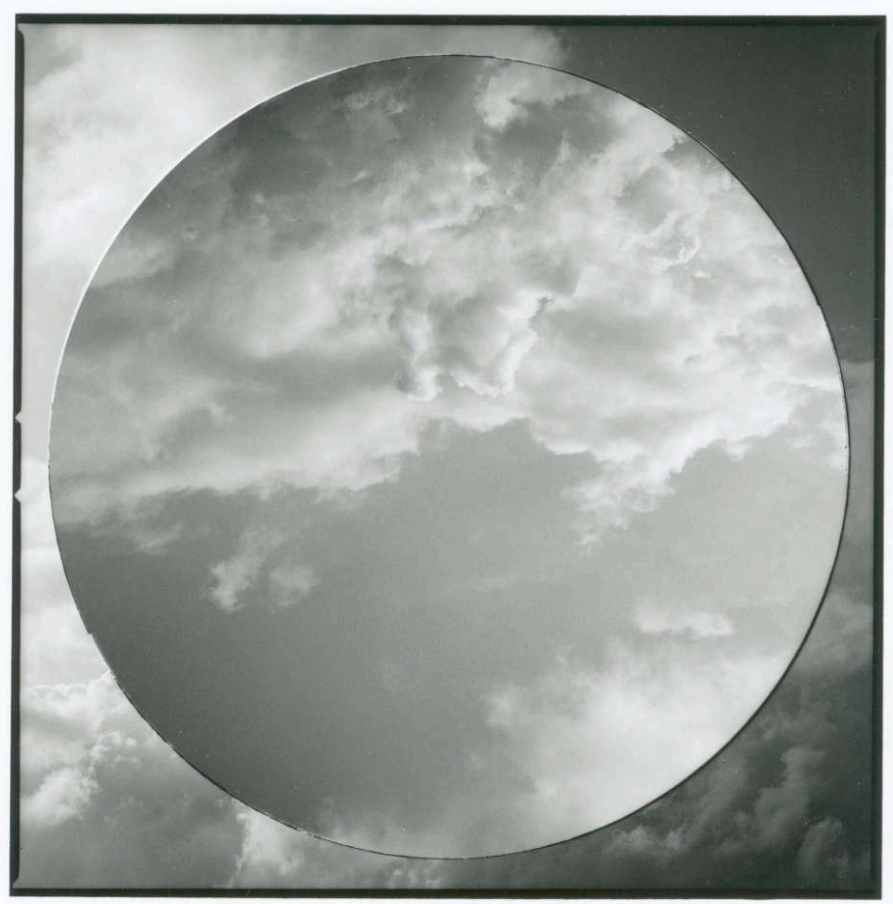

\section{(c) Courtesy of the artist.}

7 The images of my series In the Beginning mimic that bodily reality by printing a cut and rearranged circular section of negative upside down. These works also allude to the tradition that the act of picture-making is also akin to the act of creation and echo a Judeo-Christian tradition of biblical cosmology. In many illuminations of the middle ages and early modern periods, God's creation of the world takes place within the circular format of a disc or series of concentric circles, a belief that is beautifully recorded in Giovanni di Paolo's 1445 The Creation of the World and in earlier illustrations from the $13^{\text {th }}$-century Bible Moralisée (Osterreichische Nationalbibliothek, Vienna) and in the Nuremberg Chronicle. In this last example the illustration of the $4^{\text {th }}$ Day of Creation depicts a landscape with a river, sky, mountains and hills, upside down (Fig. 10). Other important narratives of the circle being a shape embodying and containing the act of creative creation is also alluded to in the art historical narratives of Giotto's O (Vasari 64-65) and in the enigmatic circles at the back of Rembrandt's celebrated Self Portrait with Two Circles of 1665-9. 
Figure 10. Aliki Braine, In the beginning... (Woodland) (2017). Black and white photograph from cut and repositioned negative, $60 \times 60 \mathrm{~cm}$.

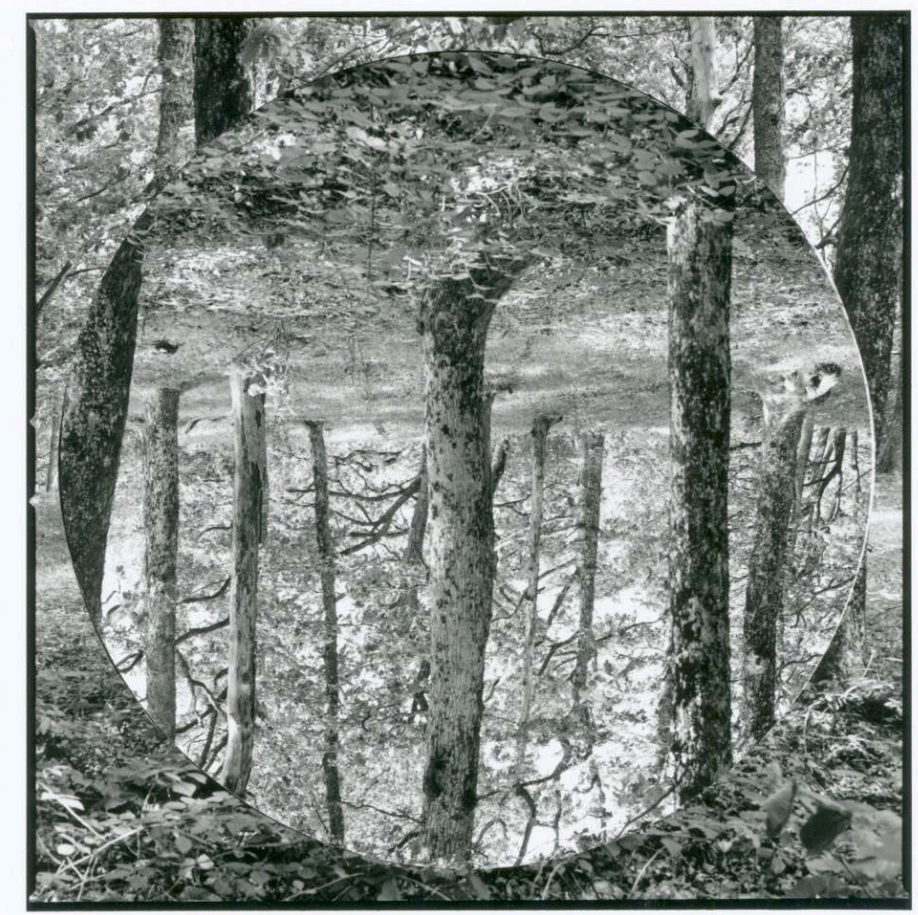

(c) Courtesy of the artist.

Despite the circle being the default shape of vision, often the format containing the act of creation and used as a symbolic motif for the skill of the artist, images are systematically made within a straight-edged format. The act of making a photograph is always construed within a rectangle; the rectangle of the negative edge, of the viewfinder, of the negative holder in the darkroom. The shapes of the photosensitive paper and their frames are also rectangular. This is perhaps why I almost always insist on including the negative edge, the black rebate, in my final prints in order to acknowledge the edge of the photograph. Whilst photographs are typically constrained within straight edges for all the reasons above, there is no fixed ratio or uniformity in the shape and size of photographic edges. Indeed, photographic paper still typically comes in sizes that echo the original large format of $19^{\text {th }}$-century glass plate photography. The ratios of camera frames, of photographic films and of photographic papers are multiple and variable. By including the negative borders in the prints of my images, I am acknowledging their edges, frames and limitations, sometimes even pushing the point home by overlapping interventions over the edges. I see my work in a direct line of historical artists from the early renaissance onwards who included trompe-l'œil motifs in their paintings which point to this desire for their images to spill out of their frames (Fig. 11) 
Figure 11. Aliki Braine, In the beginning... (Bluebell Wood) (2017). Colour photograph from cut and repositioned negative, $60 \times 60 \mathrm{~cm}$.

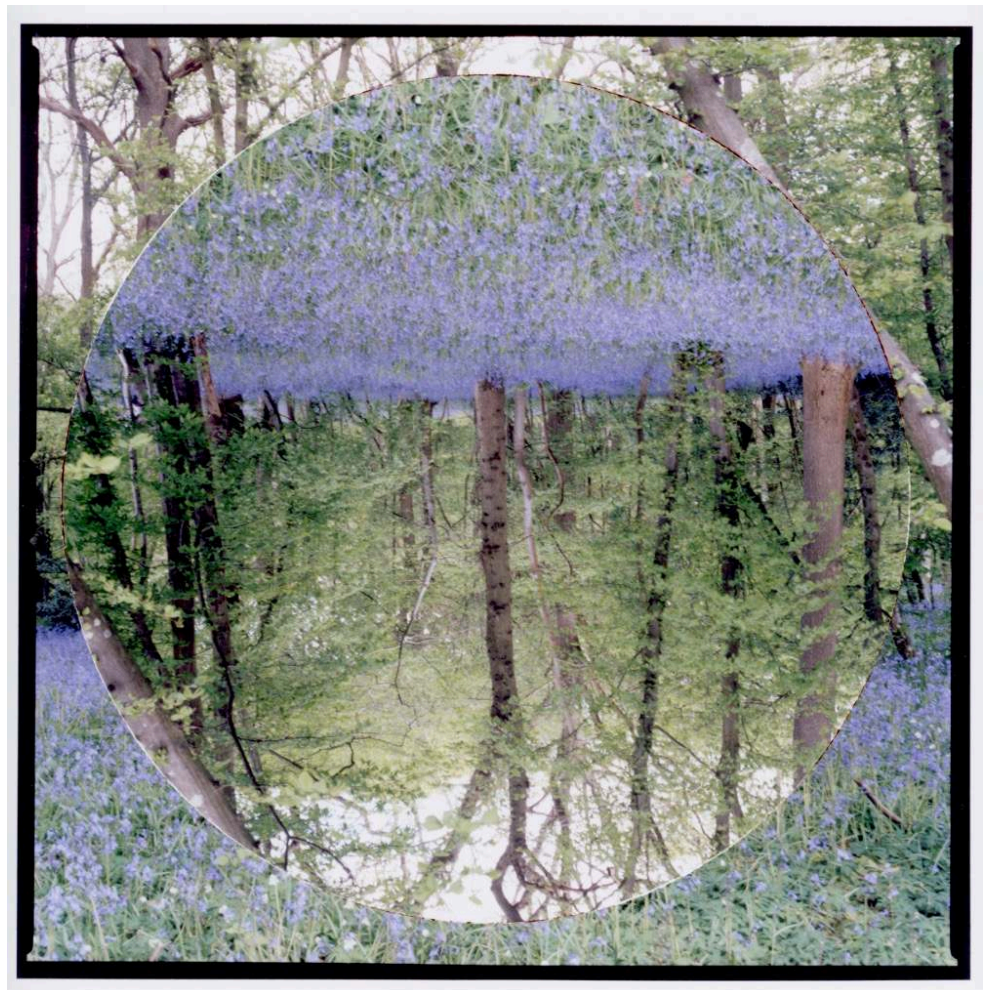

(c) Courtesy of the artist.

9 My works entitled Folded; Homage à Corot (2016), Folded; Land over Sky (2016), Folded; Where two seas meet (2018) and Folded; Lines of Desire (2018) are all made by creasing and folding the negatives before making print (Figs. 12-15). When I fold an image, it is partly a refusal to fit within its determined shape; the image spills over the edges, acknowledging the constraints of the rectangular format and, in doing so, creates fresh areas of white space within the new shape of my constructed image. The simple gesture of folding my negatives and as a consequence, allowing the image to spill outside its constraining edges, acknowledges, challenges and frustrates its format's edges. 
Figure 12. Aliki Braine, In the beginning... (Landscape) (2017). Colour photograph from cut and repositioned negative, $60 \times 60 \mathrm{~cm}$.

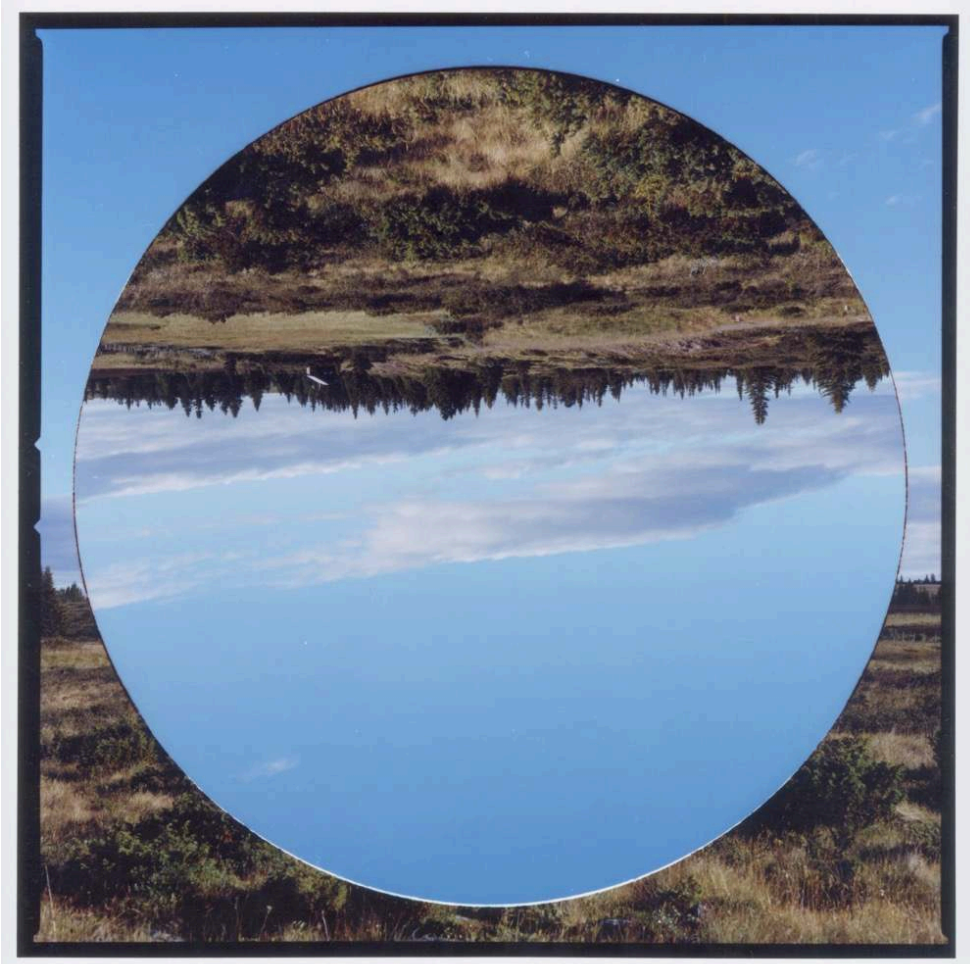

(c) Courtesy of the artist.

Figure 13. Aliki Braine, negatives.

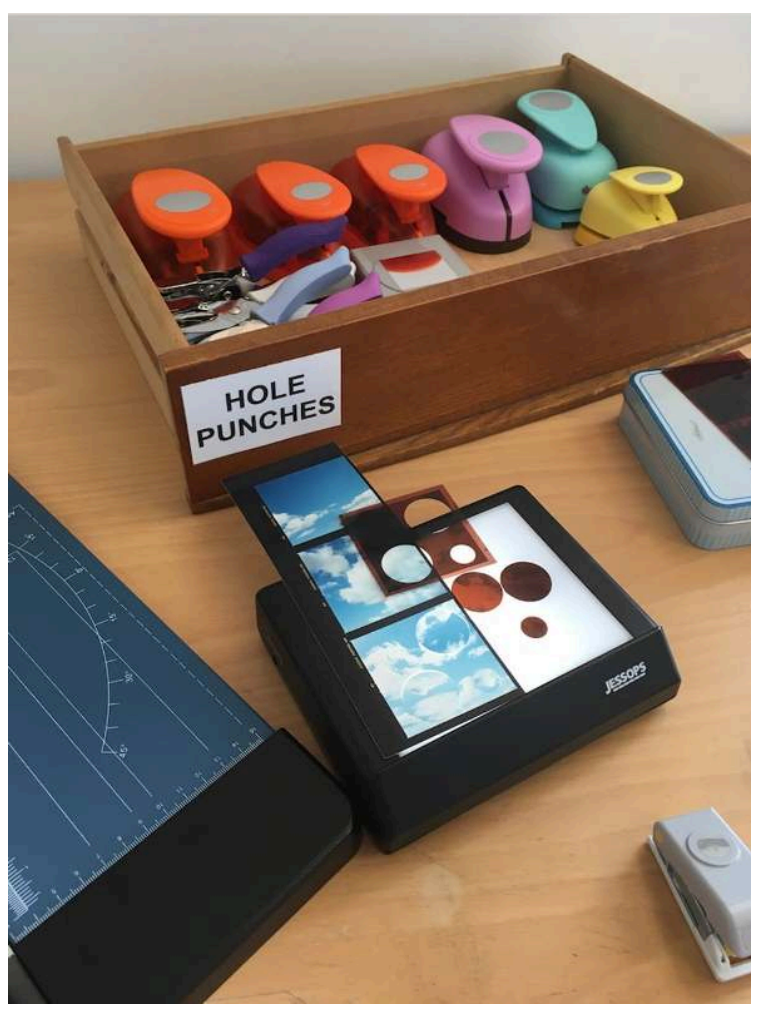

(c) Courtesy of the artist. 
Figure 14. Giovanni di Paolo, The Creation of the World and the Expulsion from Paradise (1445). Tempera and gold on wood, $46.4 \times 52.1 \mathrm{~cm}$.

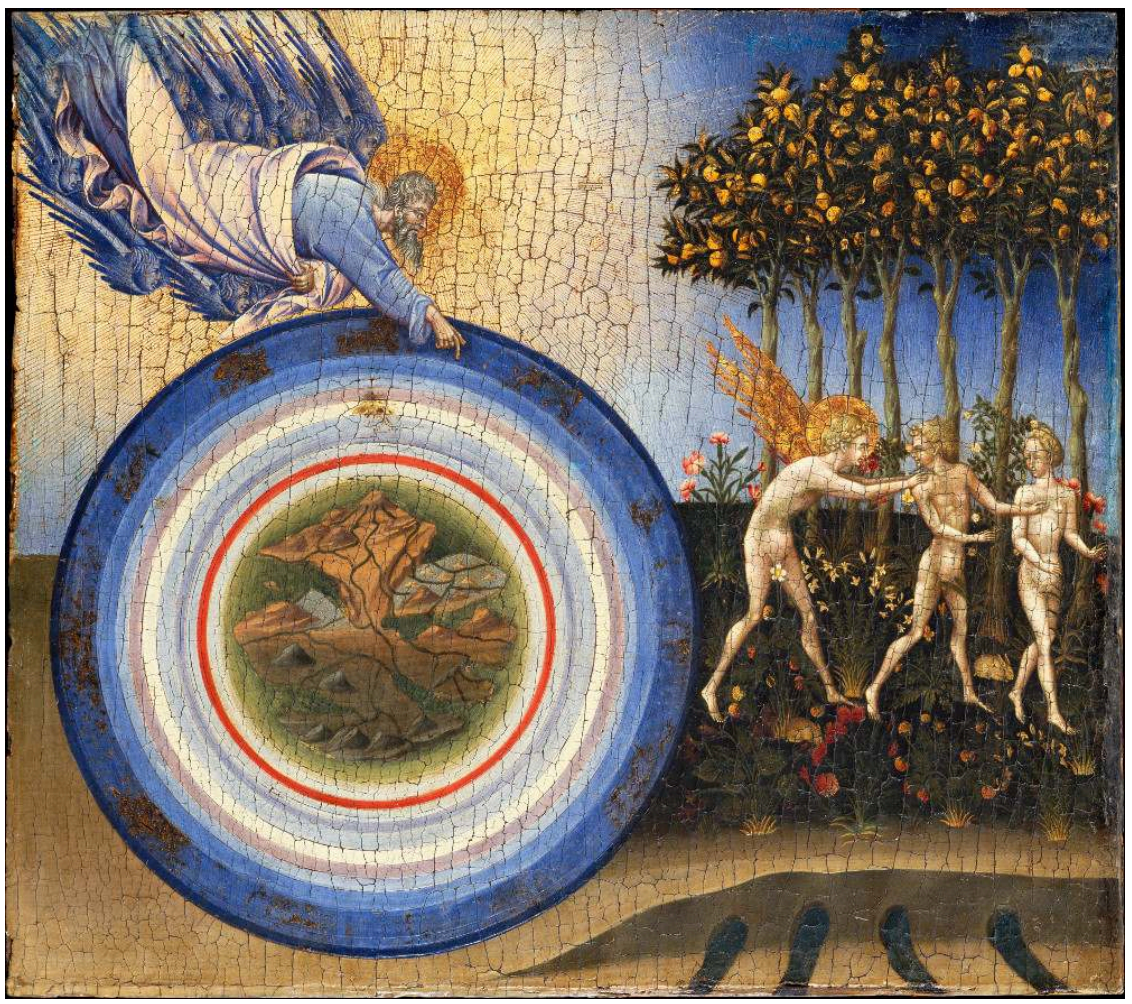

(C) Metropolitan Museum of Art. https://www.metmuseum.org/art/collection/search/458971 
Figure 15. Rembrandt, Agatha Bas (1641). Detail. Oil on canvas, $105 \times 83 \mathrm{~cm}$.

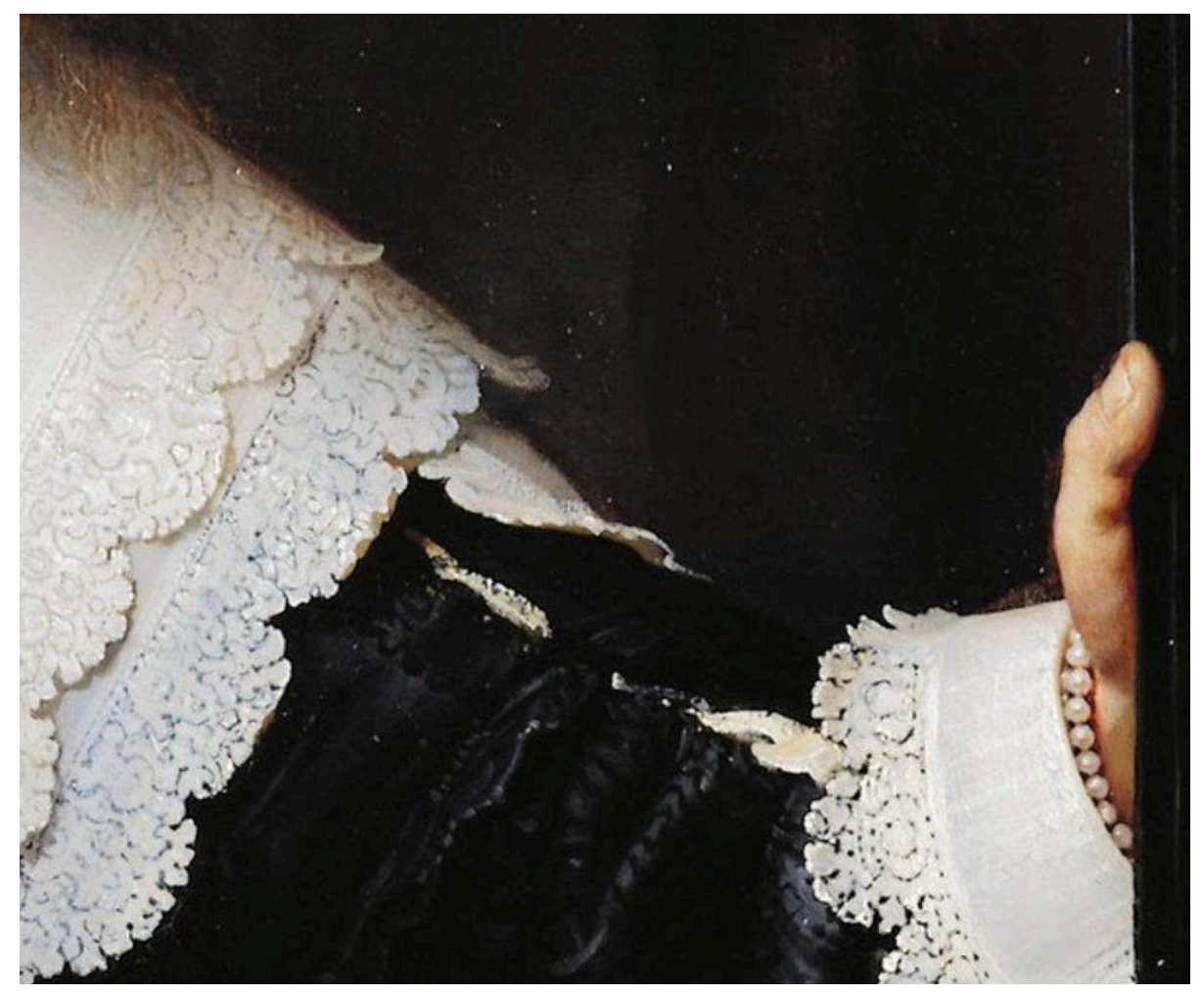

(c) Royal Collection Trust. https://www.rct.uk/collection/405352/agatha-bas-1611-1658

Figure 16. Aliki Braine, In Search of a Perfect Diagonal 1 (after Corot) (2015). Black and white photograph from folded negative, $15 \times 18 \mathrm{~cm}$.

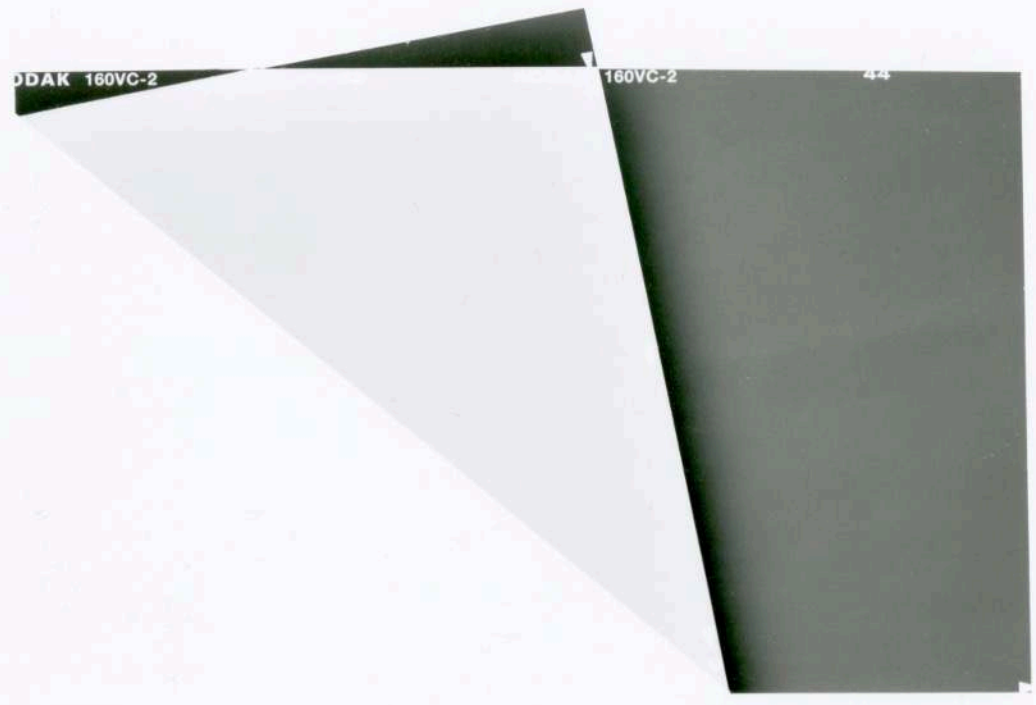


Figure 17. Aliki Braine, Folded (Homage à Corot) (2015). Black and white photograph from folded negative, $95 \times 120 \mathrm{~cm}$.

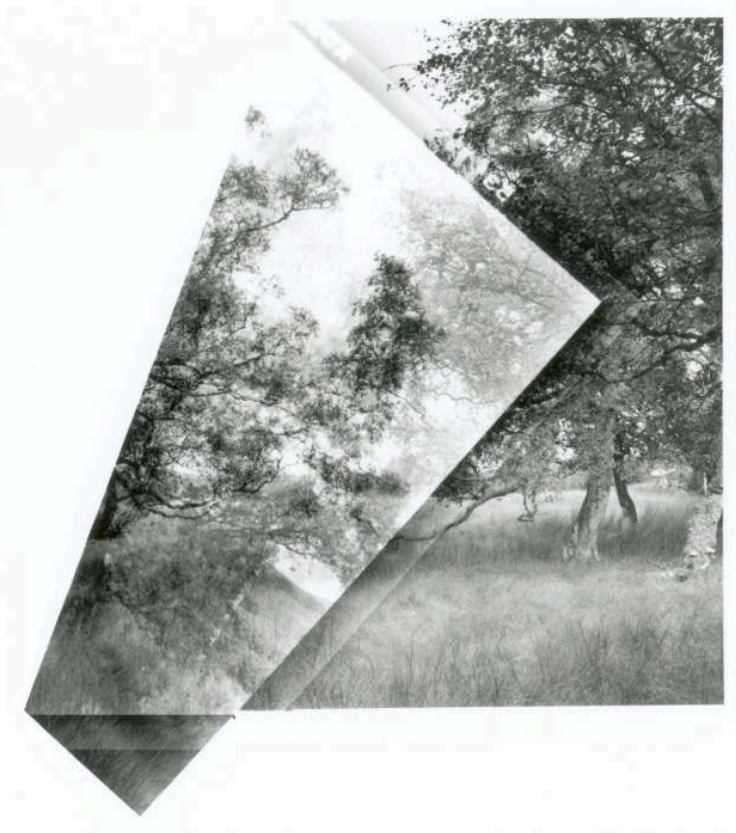

(c) Courtesy of the artist. 
Figure 18. Aliki Braine, Folded (Homage à Corot) (2015). Black and white photograph from folded negative, $95 \times 120 \mathrm{~cm}$.

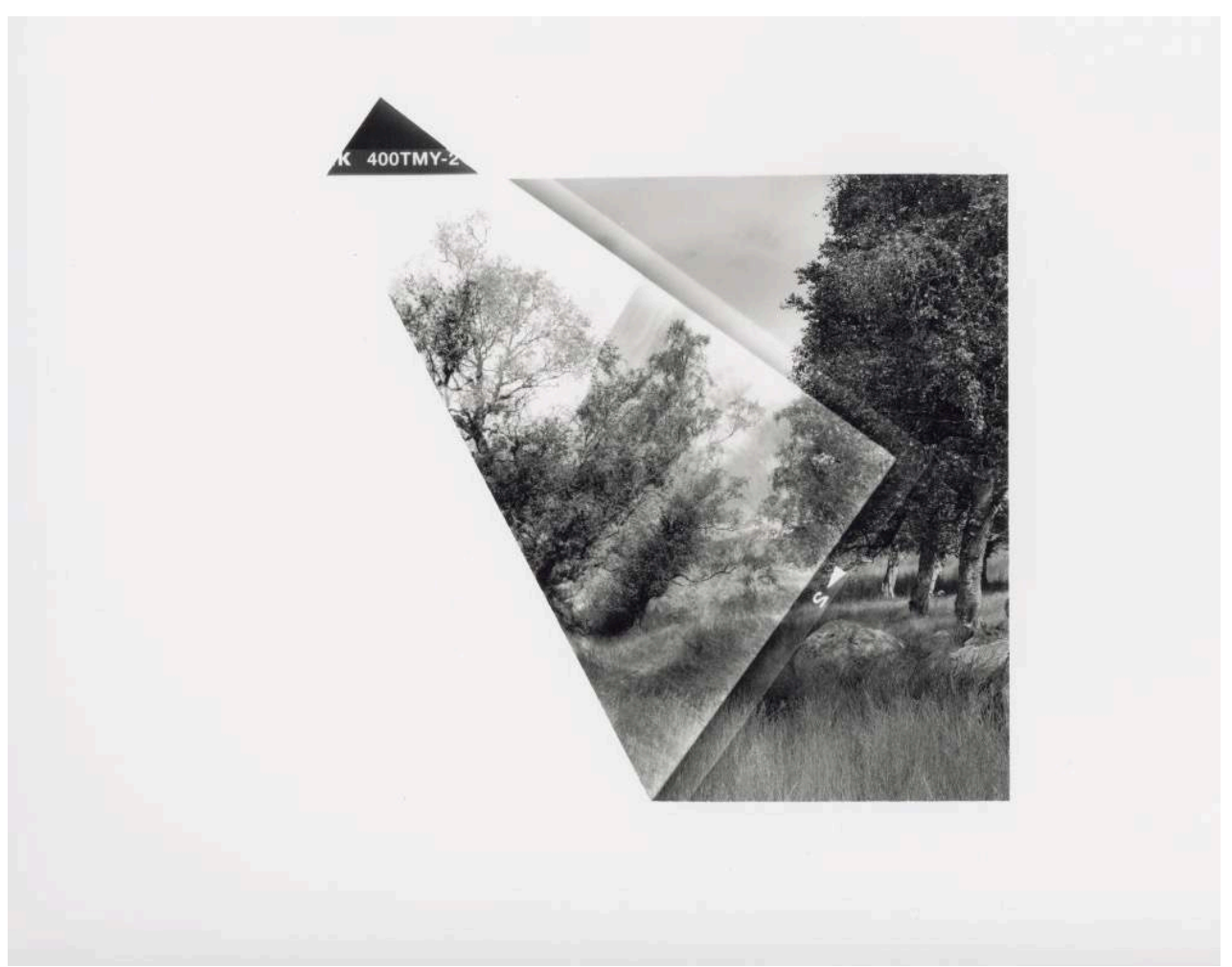

(c) Courtesy of the artist. 
Figure 19. Aliki Braine, Folded; Land Over Sky (2016). Black and white photograph from folded negative, $120 \times 80 \mathrm{~cm}$.

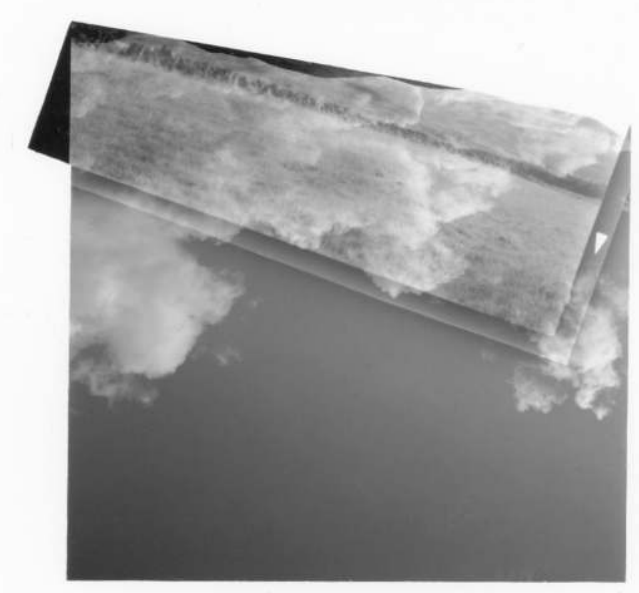

(c) Courtesy of the artist. 
Figure 20. Aliki Braine, Where Two Seas Meet (2018). Black and white photograph from folded negative, $95 \times 120 \mathrm{~cm} .2018$.

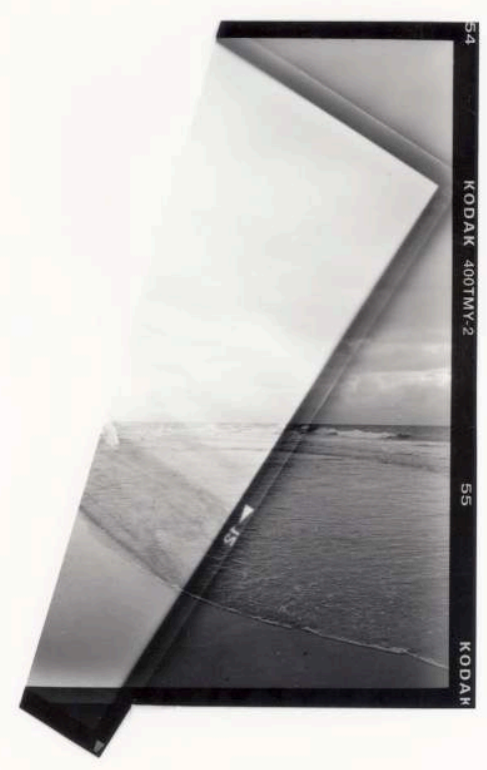

(c) Courtesy of the artist. 
Figure 21. Aliki Braine, Where Two Seas Meet (2018). Black and white photograph from folded negative, $95 \times 120 \mathrm{~cm}$.

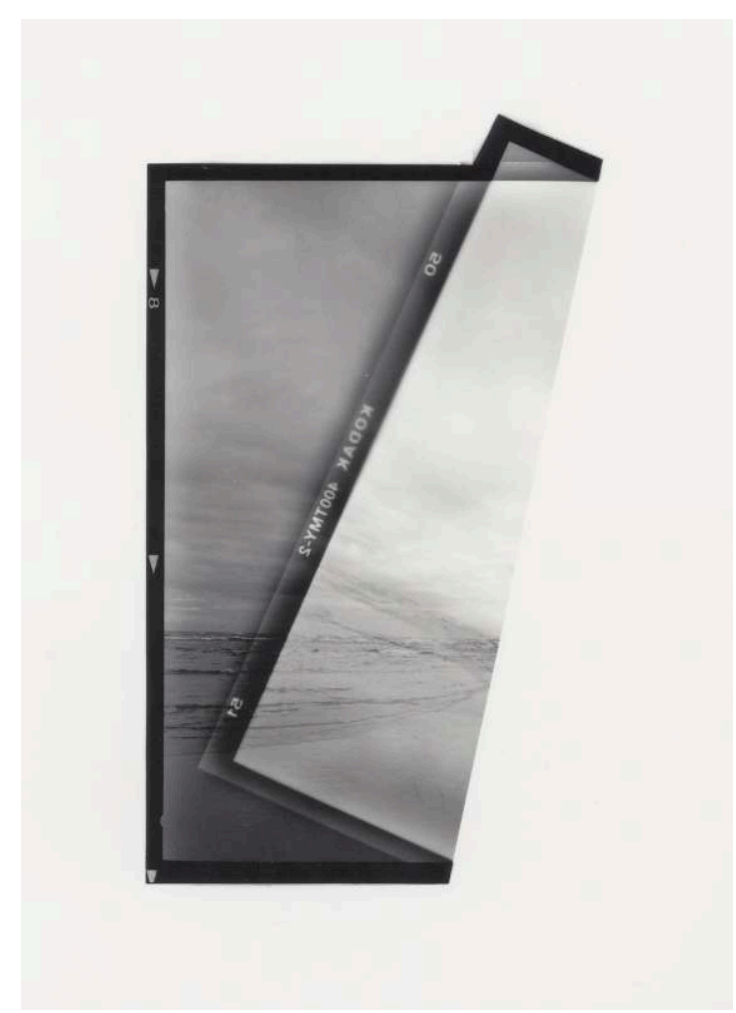

(c) Courtesy of the artist.

Figure 22. Aliki Braine, Folded, (Desire Lines, St James' Park) (2018). Black and white photograph from folded negative, $15 \times 18 \mathrm{~cm}$.

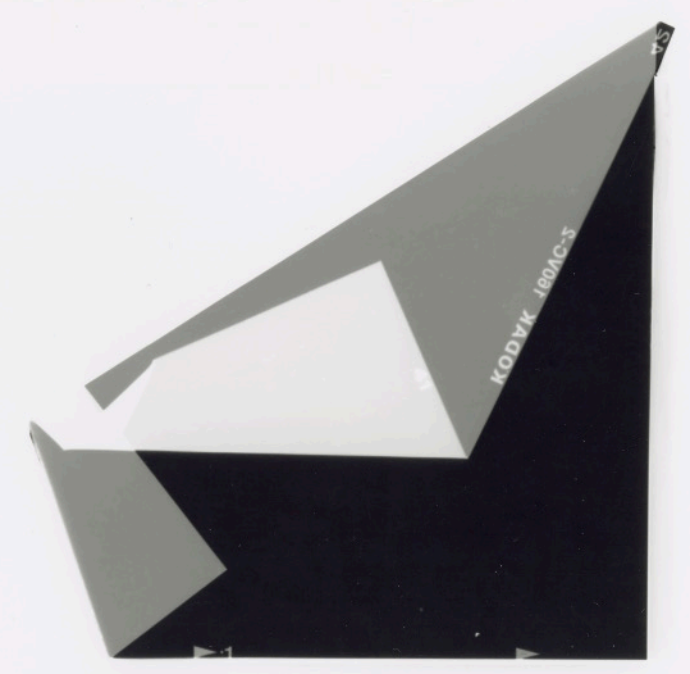

(c) Courtesy of the artist. 
Figure 23. Aliki Braine, Folded, (Desire Lines, Hyde' Park) (2018). Black and white photograph from folded negative, $15 \times 18 \mathrm{~cm}$.

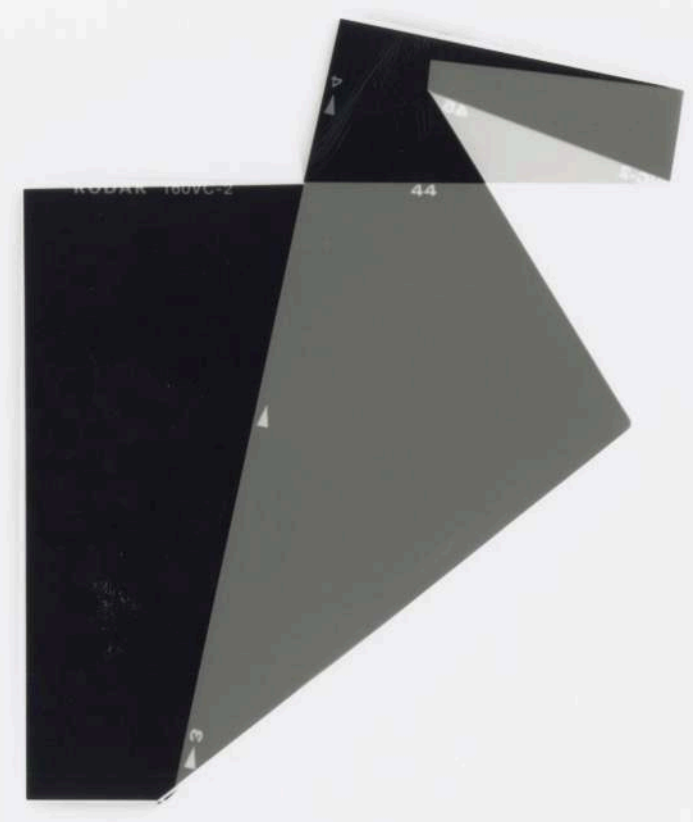

(c) Courtesy of the artist.

Figure 24. Aliki Braine, negatives.

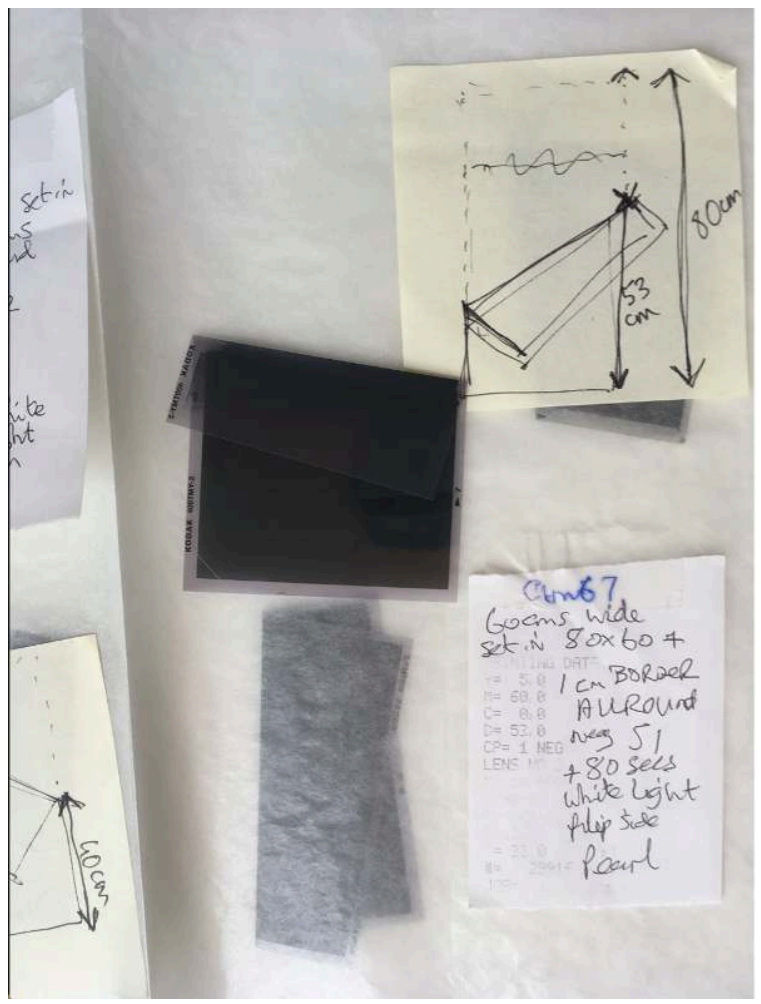

(c) Courtesy of the artist. 


\section{BIBLIOGRAPHY}

\section{Works cited}

VANAGT, Sarah and Katrien VANAGT. In Waking Hours. Balthasar Films, 2015.

VASARI, Giorgio. Lives of the Artists. Volume 1. London: Penguin Classics, 1987. Trans. George Bull.

\section{NOTES}

1. A collection of these early amateur snapshots can be viewed on The National Science and Media Museum flick page: https://www.flickr.com/photos/ nationalmediamuseum/sets/72157606845434332/ (page accessed $6^{\text {th }}$ May 2020).

2. René Descartes and Johannes Kepler were all writing and working on the nature of sight, vision and optics in the $17^{\text {th }}$ century as was Plempius who writes the following in Ophtalmographia, published in Amsterdam (1632): "I am willing to give my life to prove that the same occurs within the eye. [...] Colours and forms enter through the pupil, cleave through the fluids in the eye, arrive at the retina, adhere to it, and on this very membrane, make a painting. By means of this painting, the entire hemisphere that is in front of the eye is displayed onto the humble surface of the retina" (Vanagt, In Waking Hours).

\section{INDEX}

Keywords: artistic practice, camera obscura, creation, confetti, contemporary practice, cosmology, cutting, frame, Giotto (di Bondone), folding, photographic negative, photographic materiality, photography, Raphael, Rembrandt, Vasari (Giorgio)

Mots-clés: pratique artistique, camera obscura, creation, confetti, pratique contemporaine, cosmologie, decoupage, cadre, Giotto (di Bondone), pliage, négatif photographique, matérialité photographique, photographie, Raphaël, Rembrandt, Vasari (Giorgio)

\section{AUTHOR}

\section{ALIKI BRAINE}

Camberwell College of Arts, University of the Arts, London

Born in Paris in 1976, Aliki Braine studied at The Ruskin School of Fine Art, Oxford, The Slade School of Fine Art, London, and The Courtauld Institute where she was awarded a distinction for her Masters in 17th-century painting. Having worked for the National Gallery's education 
department for seventeen years, she is now an Associate Lecturer at Camberwell College of Art, University of the Arts, London. She also teaches at the Wallace Collection and Christie's Education and is a practising artist who regularly exhibits her photographic work internationally. Recent and forthcoming exhibitions include: A Thousand Fallen Blossoms, Argentea Gallery, Birmingham (2021), Die Blinde Fläche, Galerie Raum Mit Licht, Vienna (2019), Veronica Bailey \& Aliki Braine: Cross-Reference, dalla Rosa Gallery, London (2018), Black Out / White Out, Fruela Gallery, Madrid (2017), Les Évidences du Réel; La photographie face à ses lacunes, Musée d'art de Pully, Lausanne (2017), Material Light, Kulturni Centar, Belgrade (2015). Aliki Braine's work and practices are discussed in these recent publications: Photomonitor, Portfolio, May 2020, Elephant Magazine, Issue 32, Winter 2018/19, Robert Shore, Beg, Steal and Borrow; Artists Against Originality, Elephant Books, 2017, Pauline Martin, L'Évidence, le vide, la vie; La photographie face à ses lacunes, Ithaque Éditions, 2017, Brady Wilks, Alternative Photographic Processes: Crafting Handmade Images, Focal Press, 2015 Robert Shore, PostPhotography: The Artist with a Camera, Laurence King Pub, 2014. More info at www.alikibraine.com 